\title{
Non-invasive Analyses of Ancient Ceramics Colorants
}

\author{
Igor Lukačevića,* and Dragana Rajković ${ }^{\mathrm{b}, *}$ \\ ${ }^{a}$ Department of Physics, University J. J. Strossmayer, Trg Ljudevita Gaja 6, HR-31000 Osijek, Croatia \\ ${ }^{\mathrm{b}}$ Museum of Slavonija, Trg Svetog Trojstva 6, HR-31000 Osijek, Croatia \\ RECEIVED JULY 14, 2014; REVISED SEPTEMBER 17, 2014; ACCEPTED DECEMBER 8, 2014
}

\begin{abstract}
Present research exploits the benefits of the non-invasive and non-destructive spectroscopic methods in order to characterize the pigments which constitute the colorants found on ancient ceramic pieces. A red colorant, which occurs on the outer surfaces of the ceramic pieces excavated from archaeological finding sites Čepin-Ovčara and Kneževi Vinogradi-Osnovna škola and in earth piece from AljmašPodunavlje locality was analyzed. Using the UV-Vis FORS and Raman spectroscopy, red colorant is found to be red ochre. Raman spectrum of red ceramic colorant agrees with the spectrum of the colorant from the earth piece, leading to the conclusion that the Neolithic culture living in today Slavonija and Baranja region used the same colorants for decorating their ceramics as other nearby Neolithic cultures of Pannonian Basin. Black colorations are found to be made of soot.
\end{abstract}

Keywords: ancient pigments, non-invasive analyses, Raman spectroscopy, UV-VIS FORS spectroscopy

\section{INTRODUCTION}

Locality Čepin-Ovčara, also known as Turkish graveyard, is located $12 \mathrm{~km}$ southwestern of city Osijek of the Slavonija and Baranja region in Croatia (Figure 1). It is found in a broader lowland and plain area. Research by $\mathrm{J}$. Šimić et al. positioned a probe on the very top of the hillock, a place which was not obstructed by ploughing. ${ }^{1,2}$ Existence of thick massive walled object made of stone and brick is confirmed in this place. Object has rectangular ground plan, elongated in northwest-southeast direction. Northwestern wall is built in a shape of broad, shallow apse. Complex is, according to coins found there, dated in a period between $13^{\text {th }}$ and $16^{\text {th }}$ century. It is possible that this object was a church, whose remains are mentioned by Bösendorfer. ${ }^{3}$ After the arrival of Ottomans in the first half of $16^{\text {th }}$ century, life in this place vanquishes and has never restored again.

Multilayered historical finding site Elementary School is located in the center of Kneževi Vinogradi village (Figure 1). It is placed on the southern slopes of Bansko brdo hill on the edge of a swamp spreading the region to the former bed of river Danube. ${ }^{4}$ The rescue excavation was conducted in 2003.

Ceramics represent the most numerous kind of founds collected during archaeological excavations. Often they are the main chrono-culturological indicators of a specific period of time. Because of frequent fragmenta- tion and poor preservation of ceramic founds, multidisciplinary approach to data analyses is needed. Along with chrono-typological data analyses, we conducted spectroscopic analyses of pigment samples found on ceramic founds collected from excavation sites Čepin-Ovčara and Kneževi Vinogradi-Elementary School.

Using multidisciplinary approach, this study covers an analysis of ceramic pieces originating from Neolithic period. This analysis will provide us the answers on the nature of the ceramic colorants (red and black) and whether they coincide with the already known colorants used by nearby Neolithic cultures, like the one from the Szombathely-Oladi plato or others from the Pannonian Basin., ${ }^{5,7}$ Analysis of the earth sample from Aljmaš finding site (Figure 1) will confirm that this region is rich with natural coloring materials available to and exploitable by Neolithic cultures, like red ochre which contains haematite. ${ }^{5}$ Furthermore, we will for the first time use analytical spectroscopic methods on archaeological samples from this area, opening thus new alleys for collaboration in this multidisciplinary field of science.

Spectroscopy is by now a well-known method for studying the work of art. Recent developments (and demands of the owners of the artifacts) are bringing in front only the non-invasive (or non-destructive) spectroscopic methods in view. ${ }^{8,9}$ Most recent advances demand the use of non-invasive portable spectroscopic

\footnotetext{
* Authors to whom correspondence should be addressed. (E-mail: ilukacevic@fizika.unios.hr \& dragana.rajkovic@mso.hr)
} 

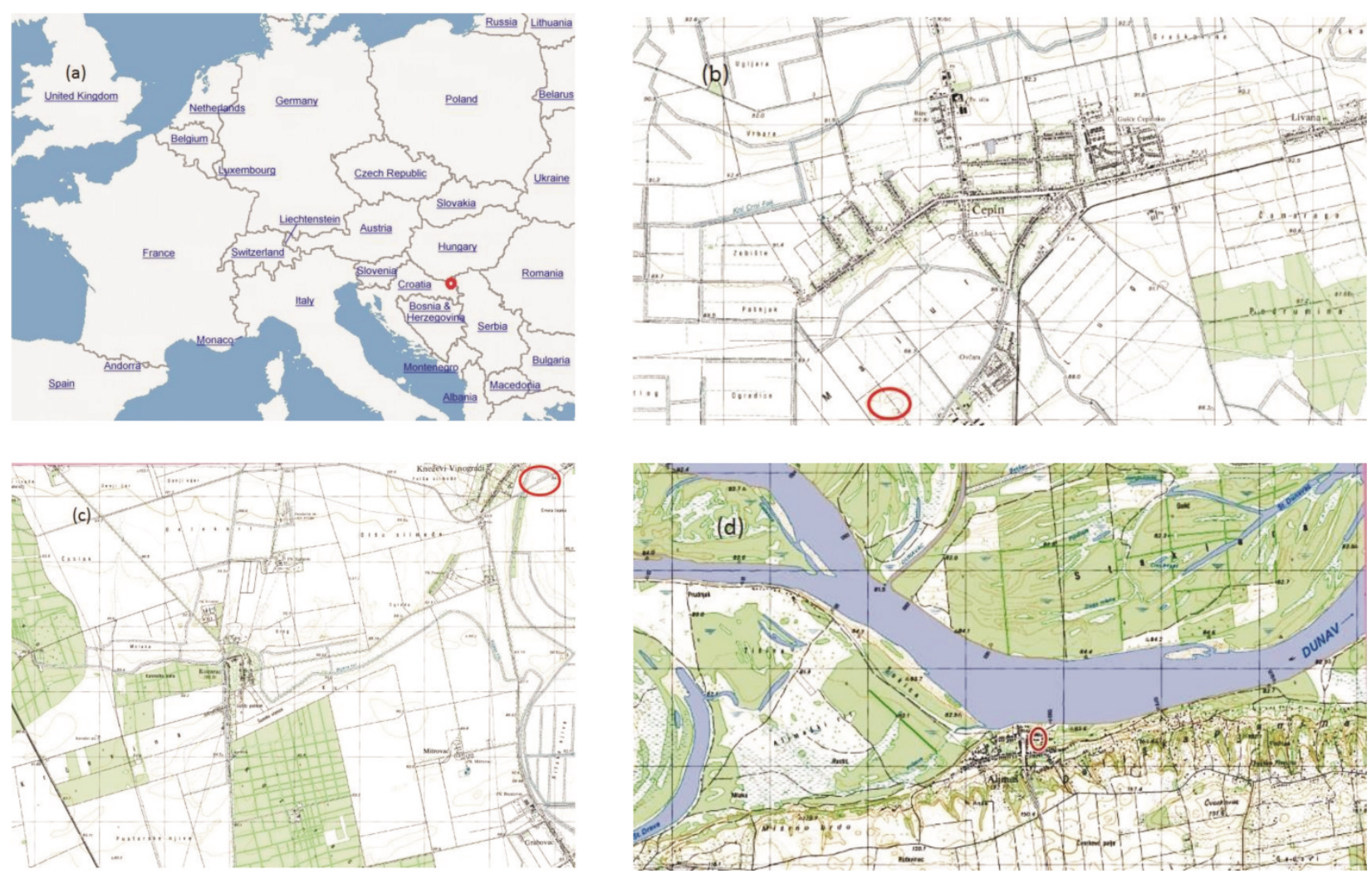

Figure 1. General location of Slavonija and Baranja region (a). Localities: Čepin-Ovčara (b), Kneževi Vinogradi-Elementary School (c), and Aljmaš (d).

analyses. $^{10}$ Portable spectroscopic equipment, using fiber optic probe heads, is especially useful when dealing with the analyses of the ancient artifacts, but it was not available to us, related to the Raman spectroscopy. ${ }^{11,12}$ The subjects of our research were in the conditions under which they could be transported from the museum to the laboratories, without risking damage to the artifacts. These conditions concern both the integrity of the color layers and the ceramic pieces themselves.

Applying Raman spectroscopy in studying the inorganic (mineral) pigments is one of the most frequent cases of applying spectroscopic techniques in the fields of art and archeology. One of the first reasons for this is the fact that inorganic pigments are such a good Raman scatterers. The obtained Raman spectra generally consist of sharp Raman bands, which provide an unambiguous identification of the pigments under study. Recorded spectral bands are, thus, readily compared with the spectral bands from the previously recorded reference spectra in the spectral databases. ${ }^{13}$

\section{METHODS}

During our study we used two different spectroscopic techniques: UV-Vis FORS and Raman spectroscopy. UV-Vis FORS (Fiber Optics Reflection Spectroscopy) spectroscopy was used because it is known that, in some cases, it can be a complementary spectroscopic method to the Raman spectroscopy. These cases are when the identification of pure and not too strongly absorbing pigments is involved. In the same time, on the other hand, one had to have in mind that it is less useful when mixtures of pigments are encountered, and that it enables a non-destructive identification of pigments only when reference spectra are known. ${ }^{9,11}$ Raman spectroscopy was used because it provides information on the molecular constituents of the crystalline phases which make the inorganic pigments. Moreover, the robust databases of Raman spectra of inorganic pigments already exist and are available on the Internet.

For reflection spectroscopy we utilized USB2000 $\mathrm{UV}-\mathrm{V}$ is spectrometer from Ocean Optics with a detector range 200-1100 nm. External light source was a tungsten halogen light bulb. For signal acquisition we used the fiber optic probe, with or without the reflection probe holder, in a diffuse mode of reflectance (at an angle of $45^{\circ}$ with respect to the surface of the ceramic pieces), as the surface of the ceramic pieces is not flat, but somewhat curved.

On-site micro-Raman spectroscopy was performed with Horiba Jobin-Yvon T64000 system using an $\mathrm{Ar}^{+}$ $514.5 \mathrm{~nm}$ laser excitation, with an output power of 20 
$\mathrm{mW}$ and with an attenuation filter of $0.3 \times$. The on sample laser power was, thus, about $7 \mathrm{~mW}$. Used laser power was checked first not to induce any significant changes on the sample. The spectral resolution was about $3 \mathrm{~cm}^{-1}$. Total accumulation times ranged from 100 seconds (for the black pigment) to 400 seconds (for the red pigment). The $\mathrm{CCD}$ detector $(1024 \times 256$ pixels $)$ was cooled by liquid nitrogen down to $140 \mathrm{~K}$.

\section{RESULTS AND DISCUSSION}

\subsection{Macroscopic observations}

\subsubsection{Locality Čepin-Ovčara}

Systematic archaeological research involved a total area of $300 \mathrm{~m}^{2}$. It was noted that a late middle-age object demolished the graveyard of Bijelo Brdo culture, which was buried in a Neolithic layer belonging to Sopot culture. Because of many over layers and grave burying, the relations between the stratigraphic units are not clearly defined nor are layers in different probes connected. According to gathered data we can conclude that stratigraphic units of this locality are: pits, half-buried residential objects, cultural layers, a well, the remains of columns and above-ground objects. The remains of above-ground objects consist mostly of parts of burned soil pathos under which are layers of coal and stuffed clay. Because of the small investigated area inside the walls of late middle-age object, no above-ground Sopot objects were studied completely. This fact makes the deeper interpretation of the investigated structures very hard. Untouched Neolithic layer was found at the depth of about $3 \mathrm{~m}$, while subsoil appeared at $5.5 \mathrm{~m}$ of relative depth. ${ }^{14}$

The oldest investigated layer of this locality was dated using carbon dating. It was found to belong in a period between $5000-4830 \mathrm{cal}$. BC. This layer probably belonged to earlier stages of Sopot culture. ${ }^{15}$ Stratigraphic unit 69 is described as a surface of ash and soot and partially of burned soil. Charcoal from this layer was dated to $4900-4720$ cal. BC. Stratigraphic unit $28 / 29$ is described as a part of large half-buried residential object of irregular oval shape with remains of thick columns. Charcoal from this layer was dated to 4860-4670 cal. BC. Ceramics found inside this dug out shows the characteristics of early Sopot culture along with particular style marks of Vinča culture. ${ }^{1,14}$ The remains of rectangular house with two levels of pathos made of stuffed soil, with a construction made of wooden boards, belong to the youngest horizon. Charcoal from this horizon was dated to $4460-4240$ cal. BC (Šimić 2006, 41). ${ }^{1,14}$

During the analysis of moveable findings from this locality we have to stress out that in the first years of research we did not pay considerable attention to historical findings, although a large amount was found. Because of that we do not have additional informations except which chamber/probe they belong to.

According to present analysis, typological properties of ceramic, stone and microlithic findings point to middle and younger stages of Sopot culture, i.e. degrees II and III by S. Dimitrijeviću. ${ }^{16}$ Findings include parts of ceramics, which belonged to pots of various profiles, decorated with plastic applied stripes with fingertip marks, biconic and conic bowls, foot chalice, miniature decanters and ceramic filters. Ceramics is mainly of grey and black color, while some fragments show red color decorations. Coarse dish has grinded particles of stone and sand in their facture, while fine dish is mostly polished. ${ }^{17}$

From the rest of the material we will mention a large amount of animal bones, shell jewelry made of Spondylus gaederopus, ceramic balls, disks made of bowl parts, chipped and polished stone tools, obsidian and ceramic anthropomorphic idol., ${ }^{2,17}$

\subsubsection{Locality Kneževi Vinogradi-Elementary School}

Archaeological research was conducted before the sports gym was built inside the complex of local elementary School. Total of 15 tranches was investigated in three parallel north-south rows located in eastern and western parts of the locality. Total investigated area was around $140 \mathrm{~m}^{2}$. Stratigraphic photograph confirmed the presence of Starčevo and Sopot cultures. We assume that in our research we covered the eastern and northeastern parts of Sopot settlement. From the archaeological findings we single out spindle ceramic spools in the shape of double crosses. Some of them have schematically human faces marked on, while one of them is decorated with cut in rhomboidal motif. ${ }^{18}$

Decorations on Sopot culture ceramic dishes were made by shallow chipping, cutting and stabbing. A significant amount of crusted painting is also present. Ceramic parts are decorated with red paint on black background, but motives are hardly recognizable. Thus, only the remains of red paint are visible. Several blackpolished thin-walled fragments of fine facture were also found, decorated with cut in motives enriched by stabbing. Some samples of handles contain the zoomorphic figurines. Findings of pillared legs stand out because they are completely colored in red paint.

From the rest of material we can point out two copper samples from which one may conclude the presence of late Sopot layer. ${ }^{18}$

Inside the pit object (stratigraphic unit 40/41) at the relative depth of $1.7 \mathrm{~m}$, a grave was found with a skeleton in shriveled position on right flank and head oriented towards west. Skeleton was positioned in an oval bier with dimensions $1.53 \times 0.95 \mathrm{~m}$. Skeleton was dated to a period between 5480-5200 BC. No grave entities were found beside the skeleton. According to 

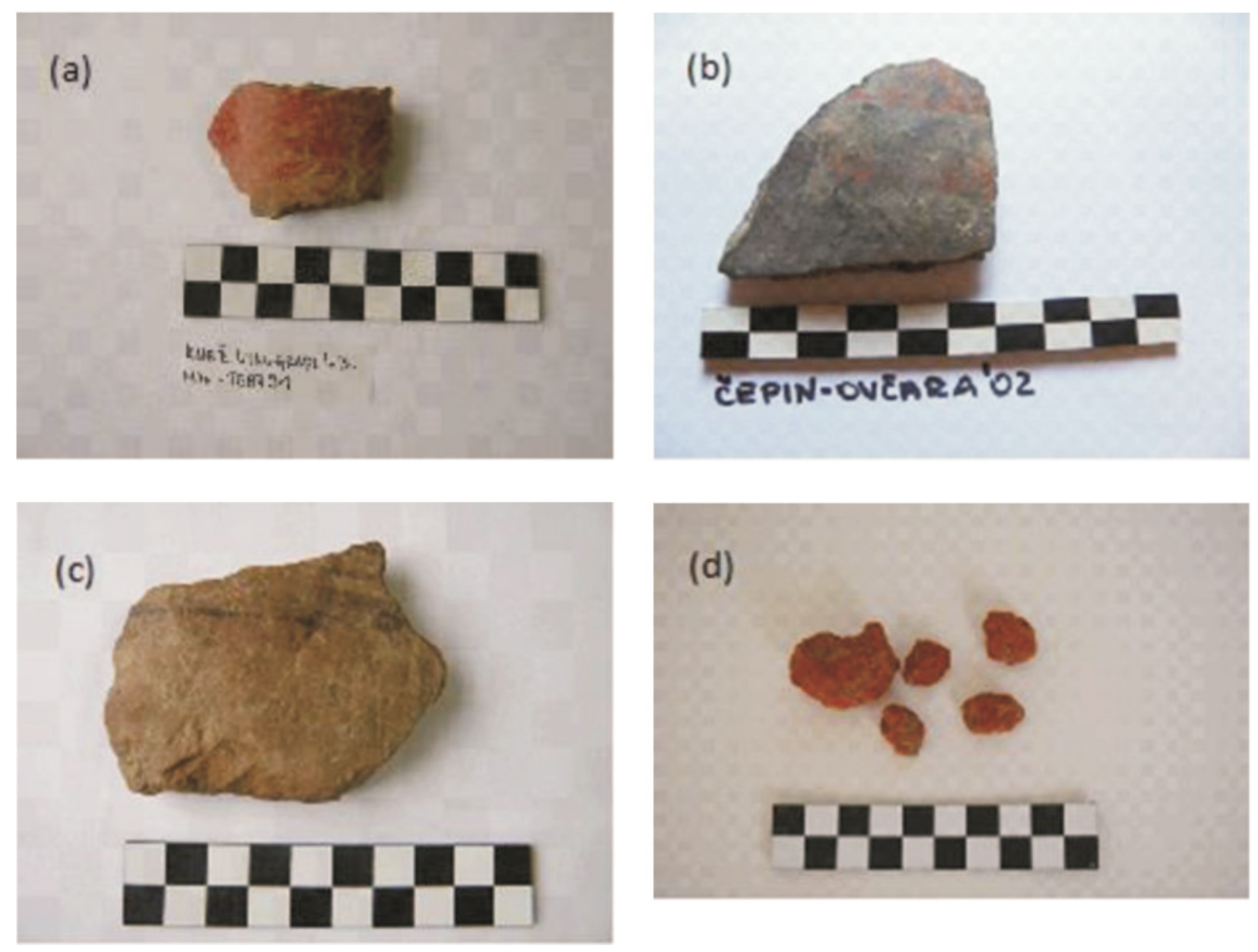

Figure 2. Colorized ceramics pieces studied using UV-Vis FORS and Raman spectroscopy: red coloration on the sample from Kneževi Vinogradi-Elementary School location (a), red coloration on the sample from Čepin-Ovčara location (b), black coloration on the sample from Kneževi Vinogradi-Elementary School location (c). Pieces of red earth sample from Aljmaš location (d).

ceramic material found inside the pit object and dating method, we ascribe the skeleton to late Starčevo culture. This is the only Neolithic grave ever found in Baranja region.

A larger number of pit objects belong to Starčevo horizon. However, they are only partially investigated because their location area larger that the investigated area. Carbon dating analysis of bone findings confirms a late stage of Starčevo culture. Same conclusions can be obtained from ceramic findings, which can be ascribed to Dimitrijević spiraloid of degree A. ${ }^{4,19}$

Archaeological material of Starčevo horizon consists mostly of ceramic fragments of different basic functional forms: pots, bowls and bowls in a shape of half-sphere. Decorations are made using various methods. On the coarse dish we found channeled barbotine, a decoration made by stabbing, pinching and plastic modelling. Painted dishes are dominated by straight-lined motives, mainly perpendicular and horizontal lines of black color on a red-brownish background and by spiral motives made after the calcination. Natural surfaces vary from red-brownish tones to ocher and dark brown ones. From the rest of ceramic findings, we can mention various weights and spools, clay disks with irregular edges of two-colored cross-section, ceramic altars and anthropomorphic and zoomorphic figurines (a snail figurine and a duck figurine).

\subsection{Spectroscopic analyses}

Studied colorized ceramic pieces are shown in Figure 2. Although the red coloration was studied on samples from localities Kneževi Vinogradi-Elementary School and Čepin-Ovčara, the resulting spectra are the same and are shown only for the sample from the finding site Kneževi Vinogradi-Elementary School.

$\mathrm{UV}-\mathrm{V}$ is reflection spectrum is given only for the red pigment and compared to the three most common antique inorganic red pigments: red ochre $\left(\mathrm{Fe}_{2} \mathrm{O}_{3}+\right.$ clay+silica), minium ( $\mathrm{PbO}$, red lead) and vermilion (HgS, cinnabar), in Figure 3. At wavelengths 


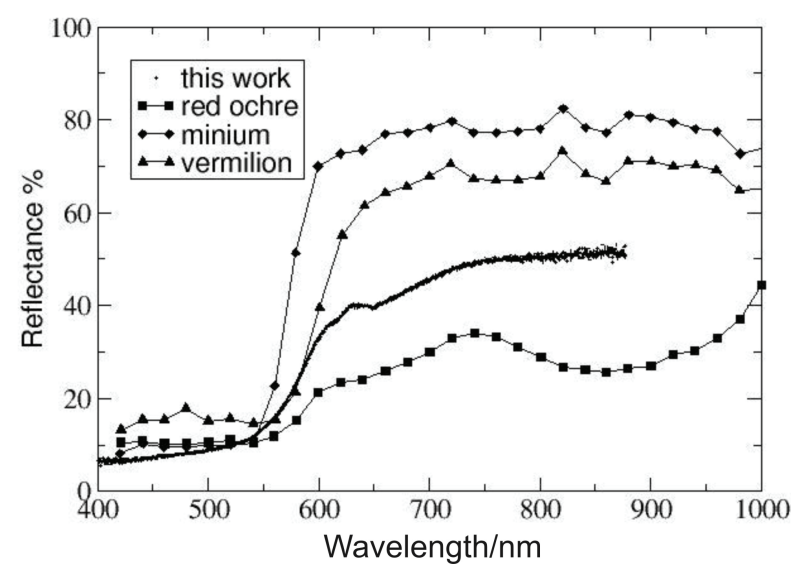

Figure 3. UV-Vis FORS spectra of red coloration (circles) and three common antic red pigments: red ochre (squares), minium (diamonds) and vermilion (triangles).

under $550 \mathrm{~nm}$, the FORS spectrum resembles more the spectra of red ochre and minium, than that of vermilion. At wavelengths above $550 \mathrm{~nm}$, the FORS spectrum of red pigment lies between the spectra of red ochre, on one side, and minium and vermilion, on the other side. Lower reflectance could indicate that the red pigment is actually red ochre, but this conclusion cannot be taken as decisive, because factors like the inconsistency of the color layers, which were worn out through time (see Figure 2), surely influenced the intensity of reflected light.

Raman spectrum of red pigment is shown in Figure 4. Bands at $223 \mathrm{~cm}^{-1}, 289 \mathrm{~cm}^{-1}, 408 \mathrm{~cm}^{-1}, 498 \mathrm{~cm}^{-1}$ and $607 \mathrm{~cm}^{-1}$ indicate that this pigment is definitely red ochre $\left(\mathrm{Fe}_{2} \mathrm{O}_{3}+\right.$ clay + silica $)$, which has the following Raman bands: $220 \mathrm{~cm}^{-1}, 286 \mathrm{~cm}^{-1}, 402 \mathrm{~cm}^{-1}, 491 \mathrm{~cm}^{-1}$ and 601 $\mathrm{cm}^{-1}{ }^{13}$ Raman spectrum of the piece of earth brought from excavation location Aljmaš reveals that red ochre is present on that location: two bands are clearly visible, at $213 \mathrm{~cm}^{-1}$ and at $273 \mathrm{~cm}^{-1}$. These results bring new light on the problem of finding out which kind of colorization agent has this culture used to decorate their pottery. They point out a possibility that it is red ochre, as it was previously thought on the basis of analogy with the nearby Pannonian Basin cultures. ${ }^{5}$ Conclusion that the studied culture used exactly red earth from Aljmaš location has to be taken with reserve, at least because of the fact that complex composition of earth, consisting of also other components besides red ochre pigment, contributes to the differences in spectral bands of red coloration and red earth sample seen in Figure 4.

A Raman analysis of black coloration reveals the usage of soot (Figure 5). Two Raman bands are clearly visible at around $1350 \mathrm{~cm}^{-1}$ and $1560 \mathrm{~cm}^{-1}$, very close to two broad Raman bands of lamp black and ivory black pigments at $1325 \mathrm{~cm}^{-1}$ and $1580 \mathrm{~cm}^{-1}$ known to be used in Neolithic period. ${ }^{13}$

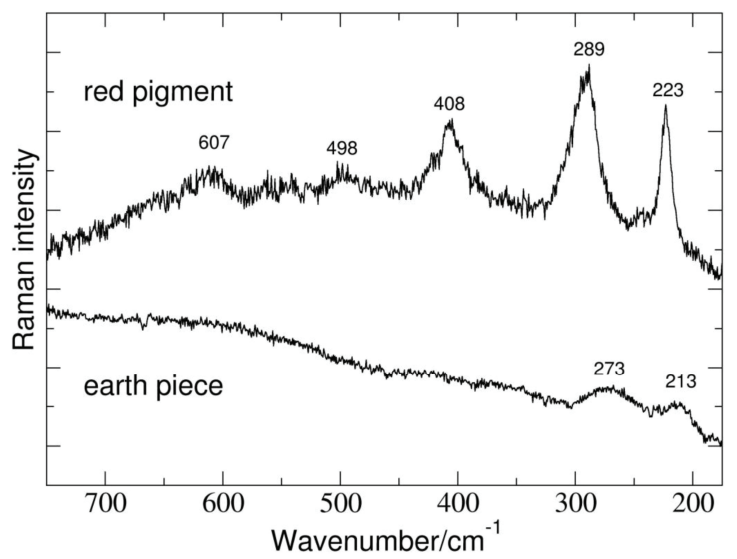

Figure 4. Raman spectrum of red coloration, consisting of the peaks belonging to red ochre pigment $\left(\mathrm{Fe}_{2} \mathrm{O}_{3}+\right.$ clay+silica $)$. A comparison with the spectrum of a piece of soil from excavation site Aljmaš is shown.

\section{DISCUSSION}

From the experimental point of view, UV-Vis FORS spectroscopy proved to be sufficient only for the qualitative analyses of red pigment, as we could not identify the nature of red pigment by comparison with other red pigments' reflectance spectra. One of the possible reasons for this is the thinness of pigment layers on the surface of ceramics, which were worn out during the passage of time. Moreover, the paint layers were inconsistent, and both these factors together caused the reflectance surface to include not only the red paint but also the surface of clay. The reflectance of clay surface interfered with the red pigment reflectance, resulting in changes in FORS spectrum.

Together with the analysis of earth sample, coloration pigment analysis, using Raman spectroscopy, confirms that this area was inhabited by the culture which had similar or lower degree of development as the near-

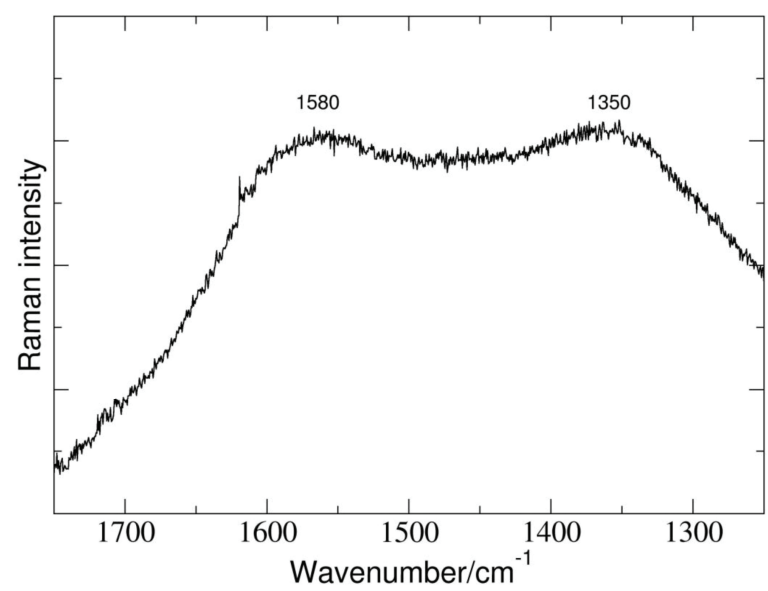

Figure 5. Raman spectrum of black pigment. 
by Neolithic cultures of Pannonian Basin. The lack of other colorization pigments found on the ceramic pieces of nearby cultures (yellow, white, orange) either confirms that this region is not as rich in colorization agent resources or that hereby culture was unaware of them or had no knowledge of their usage. Occurrence of red and black colorization (characterized as red ochre and soot) gives evidence of the cultural development of hereby Neolithic culture. They deliberately colored their ceramic ware as decoration. However, further analyses, using infrared spectroscopy (like FT-IR), are needed in order to gain more detailed answers on the methods used in the process of colorization of ceramic pieces. For example, whether they decorated their ceramic ware before or after exposure to heat. More detailed knowledge on the colorization method would shed further light on the cultural status and economic standard of Neolithic cultures originating from eastern Croatia.

Acknowledgements. Authors would like to thank dr. Davor Kirin from the Laboratory for Molecular Physics at Ruđer Bošković Institute, for giving us opportunity to use the microRaman spectrometer and for leading us through the Raman spectroscopy experiments. IL would also like to acknowledge the financial support from University of J. J. Strossmayer in Osijek, Croatia, through project "Colorants in the Neolithic Cultures of Eastern Croatia". DR would like to thank Ruđer Bošković Institute (Zagreb, Croatia), Experimental Physics Division, Laboratory for Low-level Radioactivities for ${ }^{14} \mathrm{C}$ analyses of wood coal.

\section{REFERENCES}

1. J. Šimić, Sopotska nalazišta na osječkom području, in: A. Tomaž (Eds.), Od Sopota do Lengyela-prispevki o kamenodobnih i bakrenodobnih kulturah med Savo in Dunavo, Annales Mediterranea, Koper, 2006, pp. 39-42.
2. J. Šimić, Obavijesti Hrvatskog arheološkog društva 1 (2007) $65-72$.

3. J. Bösendorfer, Crtice iz slavonske povijesti s osobitim obzirom na prošlost županija: Križevačke, Virovitičke, Požeške, Cisdravske baranjske, Vukovarske i Srijemske, te Kraljevskog i Slobodnog Grada Osijeka, u srednjem i novom vijeku, Osijek, 1910.

4. K. Minichreiter, Starčevačka kultura u sjevernoj Hrvatskoj, Zagreb, 1992.

5. Zs. Tóth, J. Mihály, T. A. L. Tóth, and G. Ilon, Archeometriai Mühely 10 (2013) 103-110.

6. N. Kalicz, Figürliche Kunst und bemalte Keramik aus dem Neolithikum Westungarns, Budapest, Archaeolingua, Series Minor 10, 1998, pp. 1-154.

7. Zs. Tóth, Savaria, a Vas megyei Múzeumok Értesítője 30 (2006) 301-359.

8. H. G. M. Edwards and J. M. Chalmers, Raman spectroscopy in archeology and art history, Royal Society of Chemistry, Cambridge, 2005.

9. E. Ciliberto and G. Spoto, Modern analytical methods in art and archeology, John Wiley \& Sons, New York, 2000.

10. P. Vandenabeele, J. Tate, L. Moens, Anal. Bioanal. Chem. 387 (2007) 813-819.

11. S. Bruni, F. Cariati, L. Consolandi, A. Galli, V. Guglielmi, N. Ludwig, and M. Milazzo, Appl. Spectrosc. 56 (2002) 827-833.

12. P. Vandenabeele, F. Verpoort, and L. Moens, J. Raman Spectrosc. 32 (2001) 263-269.

13. I. M. Bell, R. J. H. Clark, and P. J. Gibbs, Spectrochim. Acta Mol. Spectros. 53 (1997) 2159-2179.

14. J. Šimić, Hrvatski arheološki godišnjak 2 (2005) 9-10.

15. J. Šimić, Šetnje slavonskom i baranjskom prapoviješću, Osijek, 2012.

16. S. Dimitrijević, Sopotsko - lendjelska kultura, Zagreb, 1968, pp. $48-49$.

17. D. Rajković, Čepin Ovčara, in: Katalog: Darovi zemlje, Zagreb, 2014, pp. 22-28.

18. J. Šimić, Obavijesti Hrvatskog arheološkog društva 2 (2004) 74-79.

19. S. Dimitrijević, Sjeverna zona - Neoliti u centralnom i zapadnom dijelu sjeverne Jugoslavije, in: Praistorija jugoslavenskih zemalja II-neolitsko doba, Sarajevo, 1979, pp. 229-360. 